\title{
Note
}

\section{Cutaneous lymphoma development during therapy of intestinal T-cell lymphoma in a dog}

\author{
Takuya Maekawa $^{1,2}$, Kouji Nishikawa ${ }^{2}$, Shintarou Yoshida ${ }^{2}$, Kenji Sakai ${ }^{2}$, Syuuji Nishikawa²
}

\begin{abstract}
A 13-year-old intact male Shih-Tzu presented with a 2-month history of gastrointestinal signs. A mechanical ileus developed due to an obstruction from an intramural tumor in the small intestine that was surgically resected. The tumor was diagnosed as a high-grade intestinal T-cell lymphoma with incomplete margins and serosal and mesentery extension. CHOP chemotherapy (vincristine, cyclophosphamide, doxorubicin, and prednisolone) was applied, but during the CHOP protocol, the dog developed a nodule on the skin in the scapular area. Histopathological examination of a punch biopsy revealed a high-grade cutaneous T-cell lymphoma. Lomustine was administered and the cutaneous T-cell lymphoma was surgically resected and histologically diagnosed to have complete margins. However, the dog experienced progressive disease. With adjuvant chemotherapy including dexamethasone, melphalan, actinomycin D, and cytosine arabinoside (DMAC), and chlorambucil, methotrexate, and prednisolone (LMP), the patient lived for 571 days in relatively good health condition. No evidence of recurrence nor metastasis was revealed at necropsy. This case suggests the benefit of surgical resection for both intestinal and cutaneous T-cell lymphoma lesions. However, further studies are required to investigate the effect of chemotherapy, remission rate, survival time, and impact on the quality of life.
\end{abstract}

Key words : canine, chemotherapy, cutaneous T-cell lymphoma, intestinal T-cell lymphoma, surgery.

1) Maekawa Animal Hospital, 1-11-24, Heso, Ritto, Shiga, 520-3031, Japan

2) Nishikawa Animal Hospital, 23-2, Yokaichi Midorimachi, Higashiomi, Shiga, 527-0023, Japan

Corresponding author : Takuya Maekawa Tel : 077-554-7007

Email address : maekawaah@gmail.com

Received : February 17, 2020 / Accepted : October 27, 2020 


\section{T 細胞性消化器型リンパ腫の治療中に皮膚に リンパ腫の発生を認めた犬の 1 例}

前川卓哉1,2, 西川晃司 ${ }^{2}$, 吉田進太郎 ${ }^{2}$, 酒井健嗣 ${ }^{2}$, 西川秀司 ${ }^{2}$

犬の消化器型リンパ腫は犬の全リンパ腫の 5 ～7\%を占めると報告され ${ }^{[1-3]}$ 、発生部位は小腸が最も多く、胃、大腸、消化 管付属リンパ節にも生じるとされる ${ }^{[1-3]}$ 。治療法として多剂併用化学療法を行うことが勧められているものの、その有効性

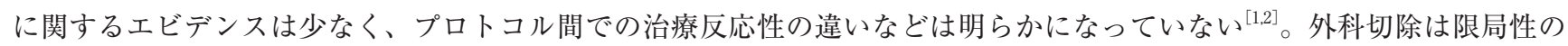
病変に対して有効である可能性は示唆されるもののまとまった報告はなく、また化学療法だけの治療法と比較して外科切除 を加えたほうが生存期間が長かったとされる報告はない。生存期間中央值は報告により13〜 77日と短く、予後因子として 化学療法に対する治療反応性、下痢の有無などが報告されている ${ }^{[1,2]}$ 。今回、消化器型リンパ腫とその治療中に皮膚へリン パ腫を生じた症例に遭遇し、外科切除および化学療法を実施することで比較的良好な経過を得られたため、その概要を報告 する。

症例はシーズー、未去勢雄、11歳3カ月齢、体重 $2.9 \mathrm{~kg}$ であった。約 2 力月前から食欲不振を認め、数日前より未消化物の 嘔吐が始まったことを主訴に来院した。初診時の身体検査において BCS1/5、体表リンパ節の腫大は認めず、犬炎症性腸疾 患活動性指数（CIBDAI）は7で中等度であった。血液検査では中等度の正球性正色素性の非再生性貧血（Hct $26.9 \% 、$ 網状 赤血球数 $43200 / \mu \mathrm{l}) 、$ 血清アルブミン濃度の低下 $(1.2 \mathrm{~g} / \mathrm{dl})$ を認め、超音波検査において小腸領域にコルゲートサイン、 腸壁の肥厚および5層構造の不明瞭化を認めた。超音波ガイド下で小腸に対する細胞診を実施したが有意な細胞は採取され なかった。第1病日よりラニチジン、メトクロプラミド、アモキシシリン、メトロニダゾールによる治療を開始したが改善 そしく、第23病日に内視鏡検査を実施し、採材した組織を病理組織学的検査およびリンパ球クローナリティー解析検査に供 したところ、リンパ球や形質細胞の浸潤の忘進、リンパ管の拡張が確認され、リンパ球のモノクローナルな増殖は検出され ず、慢性腸症と診断された。前述の治療および低脂肪・高䋊維の食事療法と対症療法により低アルブミン血症の完全な改善 はなしに症状は緩和していたが、第40病日に食欲廃絶、超音波検査において小腸領域における不完全閉塞を認めたため、第 42病日に試験開腹を実施した。術中所見において空腸の通過障害および拡張、さらにその遠位に肥厚硬結した部位を認め、 大網、腸間膜と癒着しており、これを剥離し肉眼および触診により確認される病変部よりマージンを $10 \mathrm{~cm}$ 確保した空腸部分 切除術および空腸端々吻合術を実施した（図1）。他臓器に肉眼的な異常は認めなかった。病理組織学的検査において病変部 はリンパ球様腫瘍細胞がシート状あるいはびまん性に増殖し、腫瘍細胞は中程度の大きさの核を有しクロマチン構造は粗造、 しばしば核小体明瞭であり、核分裂像がしばしば観察された。また CD3陽性であり、T細胞性高悪性度リンパ腫、マージ ンダーティ、腫瘍細胞は腸間膜や腸管漿膜においても広く病巣を形成していると診断された（図2）。第66病日よりビンクリ スチン、シクロホスファミド、ドキソルビシン、プレドニゾロンを用いた化学療法（CHOP プロトコル）（表1） ${ }^{[1,2]}$ 開始し、 良好に経過していたが、第150病日に右肩部皮膚に $2.3 \times 1.5 \mathrm{~cm}$ の腫瘤を認めた (図 3$)$ 。細胞診を行ったところリンパ腫を疑い、 第154病日にパンチ生検を実施し病理組織学的検査に供したところ、高悪性度リンパ腫と診断された。第171病日よりロムス チン (CCNU) $\left(60 \mathrm{mg} / \mathrm{m}^{2} 、\right.$ 経口、3週ごと、計2回実施）による治療 ${ }^{[4,5]}$ を開始するが、腫瘤の増大を認めたため、第214病 日に皮膚リンパ腫拡大切除を実施した。病理組織学的検査において病変部はリンパ球様腫瘍細胞がシート状に増殖し、腫瘍 細胞は中程度の大きさの核を有し大小不同がみられクロマチン構造は粗造、しばしば核小体明瞭であり、核分裂像がしばし

1）マエカワ動物病院 テ520-3031 滋賀県栗東市総1-11-24

2) 西川動物病院 †527-0023 滋賀県東近江市八日市緑町23-2

連絡責任者：前川卓哉 マエカワ動物病院％520-3031 滋賀県栗東市総1-11-24

電話番号：077-554-7007 FAX 番号：077-554-7008

メールアドレス： maekawaah@gmail.com

受付日：2020年2月17日、採択日：2020年10月27日 


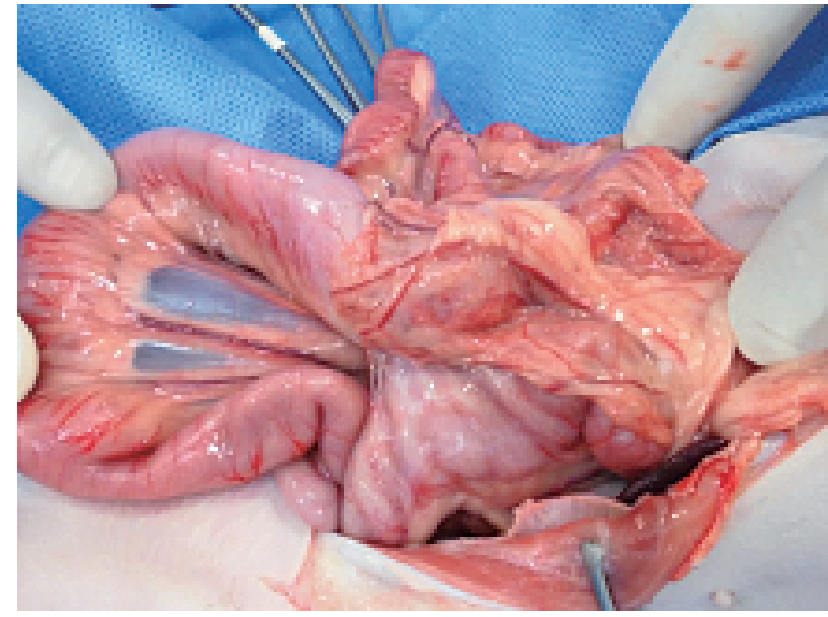

図1．第42病日 術中写真

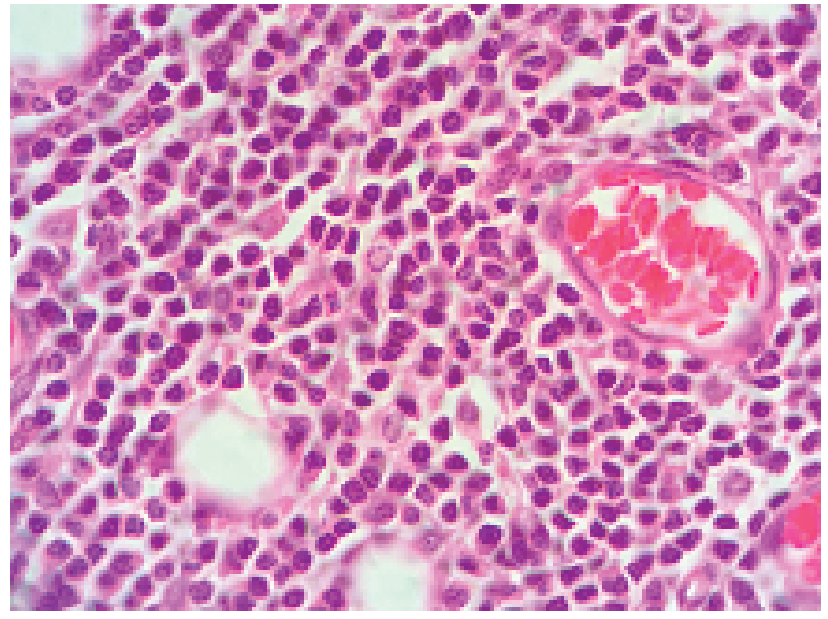

図2、腫瘍細胞がシート状あるいはびまん性に増殖（HE 染色）

表1. CHOP プロトコル

\begin{tabular}{|c|c|c|c|c|c|c|c|c|c|c|c|}
\hline 週 & 1 & 2 & 3 & 4 & 5 & 6 & 7 & 8 & 9 & 11 & 13 \\
\hline ビンクリスチン $\left(0.7 \mathrm{mg} / \mathrm{m}^{2}\right.$ 、静注 $)$ & 0 & & ○ & & & 0 & & 0 & & O & \\
\hline シクロホスファミド $\left(250 \mathrm{mg} / \mathrm{m}^{2}\right.$ 、静注） & & 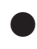 & & & & & $\sqrt{3}$ & & & & 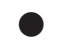 \\
\hline ドキソルビシン（30mg/m²、静注） & \multicolumn{11}{|c|}{ ○ } \\
\hline プレドニゾロン & \multicolumn{11}{|c|}{$\begin{array}{l}2 \mathrm{mg} / \mathrm{kg} \text { 、経口、1日1回 } \times 7 \text { 日 } \rightarrow 1.5 \mathrm{mg} / \mathrm{kg} \text { 、経口、1日 } 1 \text { 回 } \times 7 \text { 日 } \rightarrow 1 \mathrm{mg} / \mathrm{kg} \text { 、経口、1日1回 } \times 7 \\
\text { 日 } \rightarrow 0.5 \mathrm{mg} / \mathrm{kg} \text { 、経口、1日1回 } \times 7 \text { 日その後休止 }\end{array}$} \\
\hline
\end{tabular}

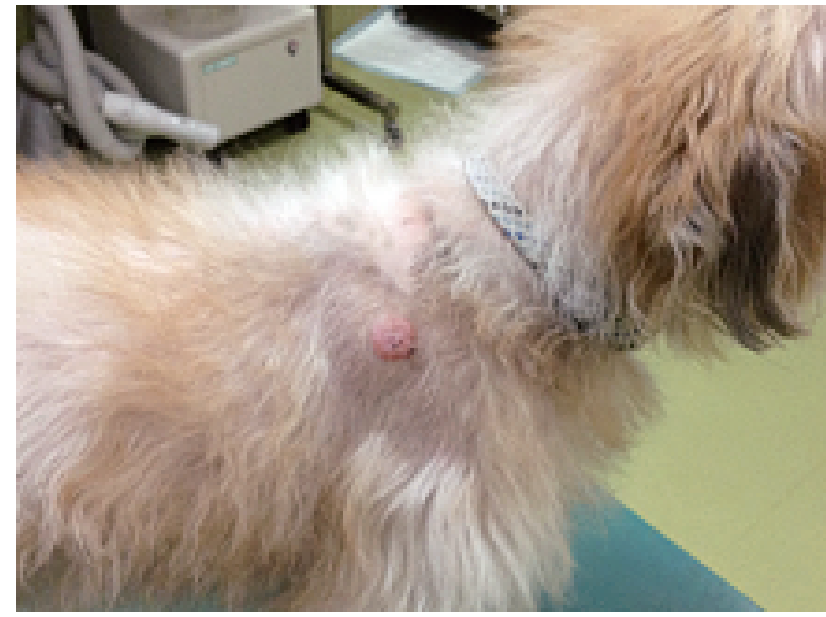

図3．第150病日 右肩部皮膚腫瘤

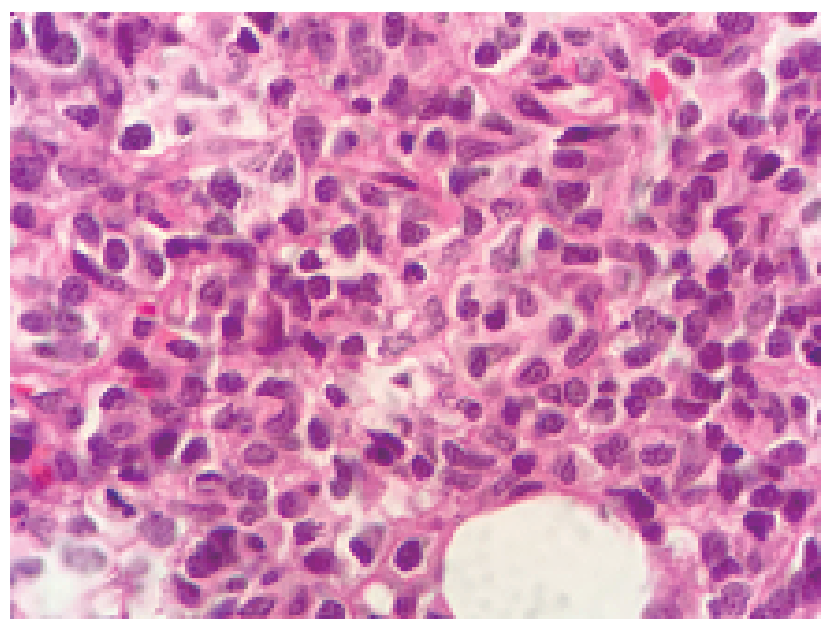

図4. 腫瘍細胞がシート状に増殖 (HE 染色)

ば観察された。またCD3陽性であり、典型的な上皮向性は認められず、 T 細胞性高悪性度リンパ腫、マージンクリーンと 診断された。第255病日よりアクチノマイシン D、シトシンアラビノシド、デキサメタゾン、メルファランによる治療（DMAC プロトコル）（表2 ${ }^{[6]}$ を開始し、良好に経過し CR を維持していたため第339病日よりメルファラン、メトトレキサート、プ レドニゾロンによる治療、第382病日よりクロラムブシル、メトトレキサート、プレドニゾロンによる治療（LMPプロトコ ル）へ変更した $(\text { 表 } 3)^{[6]}$ 。その後、食欲不振および体重減少を認めたため第455病日に内視鏡検査を実施し、採材した十二 指腸および小腸組織を病理組織学的検査に供したところ明らかな腫瘍性変化を認めず、慢性腸症と診断され、間断的な食欲 不振を認めるものの比較的良好に経過していたが第599病日に極めて重度の小球性の非再生性貧血（Hct 14.5\%、網状赤血球 数34400/ $\mu$ 1）を認めた。禀告聴取および臨床病理検査において明らかな出血を疑う所見は認めず、白血球系の数的評価お よび血小板数は正常であり、重度の炎症や腎不全、甲状腺機能低下症などを疑う所見も認めなかった。ご家族は追加検査治 


\begin{tabular}{|c|c|c|c|c|c|c|c|c|c|c|}
\hline 週 & 1 & 2 & 3 & 4 & 5 & 6 & 7 & 8 & 9 & 10 \\
\hline デキサメタゾン（1mg/kg、経口または皮下注） & O & O & O & O & 0 & O & O & O & O & 0 \\
\hline アクチノマイシン D $\left(0.75 \mathrm{mg} / \mathrm{m}^{2} 、\right.$ 静注 $)$ & 0 & & 0 & & $\bullet$ & & 0 & & 0 & \\
\hline シトシンアラビノシド（300mg/m²、皮下注） & 0 & & ○ & & 0 & & 0 & & ○ & \\
\hline メルファラン（20mg/m²、経ロ） & & $\bullet$ & & $\bullet$ & & $\bullet$ & & $\bullet$ & & 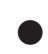 \\
\hline
\end{tabular}

表3. メルファラン、LMP プロトコル

\begin{tabular}{|c|c|c|c|c|c|c|c|c|c|c|}
\hline 週 & 1 & 2 & 3 & 4 & 5 & 6 & 7 & 8 & 9 & 10 \\
\hline メルファラン $\left(20 \mathrm{mg} / \mathrm{m}^{2} 、\right.$ 経ロ $)$ & O & & O & & & & & & & \\
\hline クロラムブシル $\left(20 \mathrm{mg} / \mathrm{m}^{2} 、\right.$ 経ロ $)$ & & & & & O & & 0 & & 0 & \\
\hline メトトレキセート（2.5 5mg/m²、経口、週2回） & 0 & 0 & ○ & 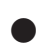 & ○ & 0 & 0 & 0 & ○ & 0 \\
\hline プレドニゾロン $\left(20 \mathrm{mg} / \mathrm{m}^{2}\right.$ 、経ロ、48時間ごと） & 0 & 0 & 0 & 0 & 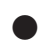 & 0 & 0 & 0 & 0 & 0 \\
\hline
\end{tabular}

療を希望されず、化学療法を休止し支持療法のみとし、第612病日に死亡した。死後12時間の剖検および病理組織学的検査 において、明らかな出血の所見は認められず、腸管および皮䖉における過去の切除部位および心臓、肺、気管、肝臓、胆囊、 腎蔵、膀胱、脾臓、消化管、膵臓、腸間膜リンパ節、大腿部骨髄においてリンパ腫を示唆する所見は認められなかった。骨 髄において細胞成分の充実性や分布に特記すべき著変は認められず、死因として慢性腸症による慢性出血性あるいは慢性炎 症性の貧血、消耗性の斃死などが考えられた。

本症例は消化器型リンパ腫の治療中に皮膚にリンパ腫発生を発生し、いずれも CD3陽性 T 細胞性、また細胞形態も類似 しており、確定はできないものの同一起源である可能性が示唆された。それぞれに局所的な外科切除を実施し、さらに長期 の化学療法を行うことで比較的良好な経過が得られ、死後の剖検および病理組織学的検査において死後融解や変性を考慮す る必要があるものの、リンパ腫関連死を示唆する所見は認められなかった。外科切除はいずれの局所の病変に対してもある 程度有効であったと考えられるが、術後の化学療法における薬剤の選択、治療効果判定や継続期間などについてさらなる検 討が必要と考えられた。

\section{参考文献}

[ 1 ] K.M.Rassnick, A.S.Moore, K.E.Collister, N.C.Northrup, O.Kristal, J.D.Chretin, and D. B. Bailey. (2006) : Efficacy of Combination Chemotherapy for Treatment of Gastrointestinal Lymphoma in Dogs. J Vet Intern Med. 23 (2) : 317 322 .

[ 2 ] Frank, J.D., Reimer, S.B., Kass, P.H., Kiupel, M. (2007) : Clinical outcomes of 30 cases (1997-2004) of canine gastrointestinal lymphoma. J Am Anim Hosp Assoc. 43 (6) : 313-321.

[ 3 ] Couto, C.G., Rutgers, H.C., Sherding, R.G., Rojko, J. (1989) : Gastrointestinal lymphoma in 20 dogs. A retrospective study. J Vet Intern Med. 3 (2) :73-78.

[ 4 ] A. S. Moore C. A. London, C. A. Wood, L. E. Williams, S. M. Cotter, D. A. L'Heureux, A. E. Frimberger. (1999) : Lomustine (CCNU) for the treatment of resistant lymphoma in dogs. J Vet Intern Med. 13 (5) :395-398.

[ 5 ] R. E. Risbon, L. P. de Lorimier, K. Skorupski, K. E. Burgess, P. J. Bergman, J. Carreras, K. Hahn, A. Leblanc, M. Turek, J. Impellizeri, R Fred 3rd, J. W. Wojcieszyn, K. Drobatz, C. A. Clifford (2006) : Response of canine cutaneous epitheliotropic lymphoma to lomustine (CCNU) : a retrospective study of 46 cases (1999-2004).J Vet Intern Med. 20 (6) : :1389-1397.

[6] M. Parsons-Doherty, V. J.Poirier, G. Monteith (2014) : The efficacy and adverse event profile of dexamethasone, melphalan, actinomycin D, and cytosine arabinoside (DMAC) chemotherapy in relapsed canine lymphoma. an Vet J. 55 (2) : :175-180. 